\title{
Martin Luther oor oneerlikheid in die ekonomie
}

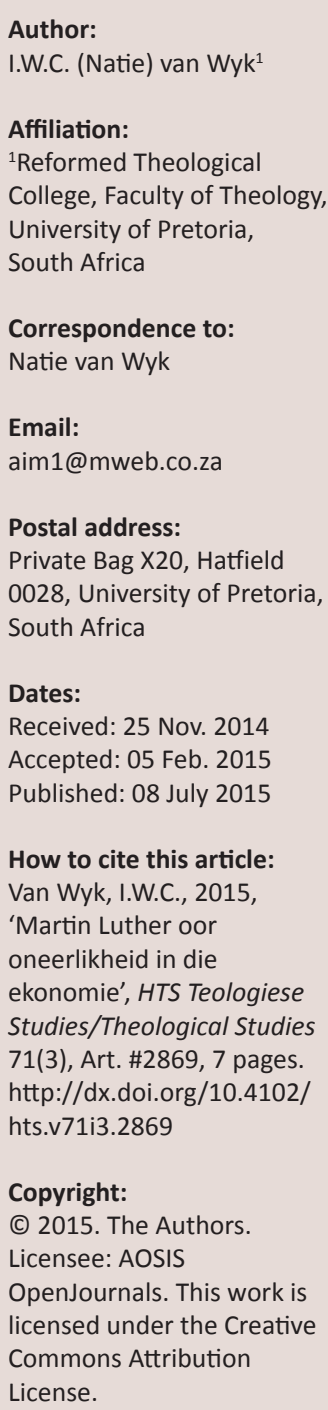

\section{Read online:}

口if Scan this Q code with your smart phone or

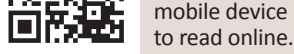

Martin Luther about dishonesty in the economy. This article is about Martin Luther's economic ethics. Background information is given about the economic situation 500 years ago. The high levels of poverty in Germany were the main reason behind the health crisis experienced at that time. Luther reprimanded the heads of families to work diligently and honestly in order to ensure a stable income for the family. He prophetically also criticised the dishonesty on the market place. He exposed the many attempts by people to exploit the poor. An overview is given of the development of his economic thought. The focus falls, however, on his essay Von Kaufshandlung und Wucher (1524) [On trade and profiteering].

\section{Inleiding}

Oor drie jaar herdenk ons die 500-jarige bestaan van die Reformasie. Gedagtig aan hierdie historiese mylpaal, is dit goed dat ons nou al begin om ons intensief met die eerste geslag van Reformatore te bemoei. Martin Luther, die vader van die Reformasie, het hom met talle vraagstukke besig gehou. Dit is dalk nie bekend dat Luther hom vir baie lank met ekonomiese vraagstukke bemoei het. Hy het hieroor gepreek, briewe en boekies geskryf en met behulp van sy kategismusse leiding gegee aan ampsdraers en lidmate. Hy het egter nooit gepoog om 'n ekonomiese etiek te skryf nie. Hy het ad rem et pro tempore op konkrete probleemsituasies gereageer. Hy het die metode gevolg om eers'n analise te maak van die konkrete omstandighede, situasies, gebeure, gedragspatrone en neigings van mense in sy direkte omgewing en om dan vanuit sy verstaan van die sosiale etiek daarop te reageer (Rieth [2009] 2010:137). Aangesien dit dus vanuit die staanspoor duidelik behoort te wees dat ons in Luther se tyd met situasie- en tydgebonde vraagstukke en antwoorde te make het, sal die vraag noodwendig opkom of ons vandag nog enige iets hiermee sou kon maak. Ek vertrou dat dit weldra duidelik sal word dat die probleme en vraagstukke van 500 jaar gelede in 'n groot mate nog steeds dieselfde uitdagings is waarmee ons worstel - alhoewel, vanselfsprekend in ander gestaltes. Inaggenome die analogieë wat verskillende periodes en omgewings wel uiteindelik gemeen het in die uitdrukking van die menslike drange van gierigheid en misbruik van die medemens, behoort ons in te sien dat Luther se etiese oordele nog steeds van waarde is. Kleiner detail in sy argumentvoering mag nie meer relevant wees nie, maar die hoofargumente bly insiggewend.

Die artikel word soos volg ingedeel: 'n vlugtige skets van die ekonomiese omstandighede in Luther se tyd, die ontwikkeling en algemene kenmerke van sy arbeidsetiek, 'n gedetailleerde bespreking van een van sy bekende geskrifte oor die woekerpraktyk en 'n samevattende waardering van sy arbeidsetiek.

\section{Martin Luther en die ekonomie}

\section{Sosiaal-ekonomiese omstandighede en samelewingstrukture}

In die sestiende eeu was nagenoeg een kwart van die Duitse bevolking arm en siek. Veral die plattelandse gesinne het swaar onder aanhoudende armoede gely (vgl. Schirmer 2007). Armoede het hand aan hand gegaan met siekte. Talle siek mense was arm of in die proses van verarming, en arm mense was blootgestel aan allerhande siektes, en as gevolg van hulle armoede kon hulle nie mediese dienste bekostig nie. Luther se belangstelling in die ekonomie het dus gegroei uit pastorale bewoënheid jeens siek lidmate in Wittenberg. Om siekes te help en om siektes te beveg, moes mense gehelp word om nie te verarm nie. Verarming het dikwels verband gehou met ekonomiese onreg en korrupsie, en daarom het Luther hom geroepe gevoel om onaanvaarbare ekonomiese praktyke te ontbloot en te beveg. ${ }^{1}$

Luther was nie net 'n geleerde mens wat teoreties oor probleme nagedink het nie, hy het ook prakties probeer om arm en siek mense te help. Die een manier hoe hy dit gedoen het, was deur

1.Daar kan natuurlik ook na ander gebeure en omstandighede verwys word, soos die boere-opstande van 1522-1525 wat Luther se mening oor ekonomiese sake help slyp het. Ek kies om nie op hierdie gekompliseerde terrein in te gaan nie, aangesien die artikel dan té lank gaan raak. Belangstellendes kan kyk na Schilling ([2012] 2014:276-316) vir die nodige inligting. 
die hervorming van bestaande finansiële dienste en instellings. Hy het meegewerk aan die hervorming van die 'Wittenbergse Beurs' wat geld beskikbaar gestel het vir die hospitaalversorging van siekes (veral dié met Franzosenkrankheit - 'n ekstreme vorm van sifilis) en geestesgestremdes (dalk een van Luther se grootste prestasies). Daarnaas het hy toegesien dat die 'gemeenskapskas vir sosiale behoeftes' deur sy vriend Johannes Bugenhagen behoorlik geadministreer word ter opheffing van die armes en siekes. Hy het Bugenhagen gemotiveer om nie té veel geld aan kerkgeboue te bestee nie, maar om die geld eerder aan te wend vir diakonale dienste (vgl. Jütte 2007). 'n Mens moet Luther ook die krediet gee dat hy, méér as ander, daarvoorgesorghet dat diebedelaarskultuur in Wittenberg en omgewing vervang is met ' $n$ kultuur van arbeid (vgl. Bräuer 2007). Bedelaars van buite die Protestantse dorpe en stede het nie vir finansiële hulp gekwalifiseer uit die 'fonds vir armsorg' nie - 'n spesiale fonds wat Luther in die 'gemeenskapskas' geskep het. Slegs 'waardige armes' is gehelp. Leeglêers en niksnutte is nie gehelp nie. Dieselfde reël het vir immorele mense gegeld. Slegs diegene wat bereid was om te werk, asook mense met die nodige morele integriteit, is uit hierdie fonds gehelp (vgl. Oehmig 2007:110-114). Met reg kan beweer word dat Luther' $n$ enorme aandeel gehad het aan die Duitse etos van hardwerkendheid, stiptelikheid en noukeurigheid.

\section{Die teologiese ontwikkeling van sy ekonomiese etiek}

In Luther se eerste geskrif wat bekendheid verwerf het, naamlik die 95 Stellings teen die Aflaat / Die Ablassthesen und die Resolutionen 1517/1518 (1981a:58 = WA 1, 530, 600-601), het hy al opmerkings oor die ekonomiese etiek gemaak. Die volgende perspektiewe sou die ontwikkeling van sy ekonomiese etiek begelei:

43. Daaroor moet Christene onderrig word: Om vir ' $n$ arm mens te gee en aan 'n behoeftige te leen, is beter as om 'n aflaat te koop.

45. Daaroor moet Christene onderrig word: Wie van 'n behoeftige wegkyk en aflate koop, kom nie binne die werkingsveld van die Pouslike aflaat nie, maar kom te staan voor God se toorn.

46. Daaroor moet Christene onderrig word: Wie nou nie juis in oorvloed lewe nie, is juis verplig om na sy huisgesin om te sien. Niemand mag sy [gesinslewe] vernietig ter wille van aflate nie. (Outeur se vertaling)

Luther meen dus dat bydraes tot die bou en instandhouding van die Petruskatedraal in Rome nie 'n Christen se barmhartigheidsverpligting en sy verantwoordelikheid jeens sy gesin mag benadeel nie. Hiermee val hy nie primêr die gedagte van kerkbou aan nie, maar onverantwoordelike optrede wat armoede kan aanblaas. Verantwoordelike huweliks- en gesinslewe voorkom verarming en die agteruitgang van die gesondheidsvlakke van die gemeenskap (vgl. Beyer 2007:60-61).

Luther het sy denke oor die ekonomie ontwikkel deur herhalend te poog om uitleg te gee aan die sewende en negende gebooie. In 1518 het hy (vgl. WA 1, 500, 28-502.26) in preke begin praat van die 'vier werke teen die sewende gebod', naamlik diefstal, gewelddadige afneem van besittings, woeker en bedrog in handel. Hy was ook bewus van die feit dat daar in die regspleging van vyf aspekte van diefstal gepraat is, naamlik direkte diefstal (furtum simplex), tempelroof (sacrilegium), diefstal van publieke geld of korrupsie (peculatus), skelm stelery (abigeatus) en plagiaat (plagiatus). Volgens Luther kan hierdie interpretasies help om 'diefstal' te verstaan en te verduidelik, maar dit bring jou nog nie by die kern van die probleem uit nie, naamlik die 'begeerlikheid' waarvan die negende gebod praat. Begeerlikheid gaan terug op die sondeval, en hiervan weet die juriste niks nie. Die teoloë moet die volk hieroor onderrig. Luther het geweet waarvan hy praat, aangesien hy self 'n slagoffer van diefstal (wat ten diepste met begeerlikheid te make het) was. Komies en tragies tegelyk is die diefstal van sy 1525 Bybelvertaling uit die drukkery in Wittenberg deur 'n drukker van Nürnberg (Rieth [2009] 2010:142).

In sy Klein en Groot Preke oor Woeker (Luther 1519 en 1520 WA 6, 1, 3-8; 6, 33, 36-60) het Luther gepleit dat daar nie net teoreties oor armoede nagedink moet word nie, maar dat die gemeente ook op 'n praktiese wyse armes moet help. Hierdie hulp moet by die Nagmaaltafel begin. Nadat die gemeente 'geestelike voedsel' aan die tafel ontvang het, moet hulle aardse voedsel skenk om die armes te voed. Luther was dus die eerste Reformator wat gepleit het vir die onlosmaaklike band tussen Nagmaal en barmhartigheid (Beyer 2007:62). Die Switserse Reformasie sou egter hierdie insig verder ontwikkel. Danksy die Switsers handhaaf ons die mooi praktyk om geld vir barmhartigheidswerk onder die Nagmaaltafeldoek te los (vgl. Van Wyk 2010). Naas die voedselhulp wat Luther tydens Nagmaal laat versamel het, het hy ook 'n klomp ander waardevolle dinge gedoen as voortsetting van sy verkondiging. Hy het orals, maar veral in hospitale, higiëne laat verbeter en begraafplase buite Wittenberg laat ontwikkel - nie net om siektes te bekamp nie, maar om aan plattelanders waardigheid in die dood te gee (vgl. Beyer 2007:68).

In 1520 lewer hy sy Preek oor die Goeie Werke $(1991 \mathrm{~b}=W A$ 6, 204-250). Hierdie was die eerste Protestantse etiek in die vorm van 'n uitleg van die tien gebooie. Van belang is dat hy hier die 'vaderskapsgebooie' begin uitlê het aan hand van die 'drie-stande-leer'. Op voetspoor van Aristoteles het Luther die sosiale werklikheid ingedeel volgens drie stande ${ }^{2}$ of klasse, te wete die kerk (ecclesia), die staat (politia) en die gesin (oeconomia). Hierdie drie klasse word verteenwoordig deur die priester, vors en huisvader. Die vader as die hoof van die huishouding het dus ' $n$ besondere verantwoordelikheid jeens sy gesin. Die ekonomie is in sy hande, en hy moet sorg dat sy gesin nie in armoede verval en siektes ontwikkel nie.

2.Die woord "stand" is vir ons 'n vreemde begrip, afkomstig uit die Middeleeue. Dit omskryf die verskillende groepe en sosiale lae van die gemeenskap. Dit omskryf die 'stand', die 'beroep' en die 'regiment' waarbinne mense hulle kan bevind. Hierdie "stand, die 'beroep' en die 'regiment' waarbinne mense hulle kan bevind. Hierdie begrip beskryf die sosiale werklikheid nie as 'n statiese toestand nie. Luther was bewus van die vloeibaarheid van die werklikheid. Dit verwoord ook die etiese perspektiewe op die sosiale werklikheid, en wel in terme van'n private, politieke en ekonomiese oordeel oor wat ons omgewe. Om hierdie rede het hy gemeen dat $h$ as teoloog wel'n mening oor die ekonomie kan uitspreek. As Christen leef hy ook binne die ekonomiese werklikheid en die ekonomie kan nie totaal los van die geloof funksioneer nie (vgl. Rieth 2010:138-140). 
Hy verwag van die vaders om vrygewig (Mildlich) te wees. Die vader moet ander help om hulle besittings te behou en te vermeerder. Hy waarsku hulle teen diefstal, roof, begeerlikheid en woeker (om goedere té duur te maak en om onakkurate skale te gebruik). Christene het nie nodig om oneerlik geld en goed te bekom nie, aangesien hulle vanuit die geloof lewe dat God mildelik sal voorsien. Hierdie gedagte het Luther alreeds sedert 1516 gereeld in die prediking na vore gebring (vgl. Brandt 2011).

In sy An den christlichen Adel deutscher Nation von des christlichen Standes Besserung (Adelgeskrif) van 1520 (1991c:159-166 = WA 6, 407, 10-411) argumenteer hy dat die owerhede of regente die verpligting het om wetgewing aan te pas om onregmatige woeker te bekamp, bordele af te skaf, geldverkwisting op luukshede te beperk en oormatige etery hok te slaan. Sonder gesonde oorhoofse wetgewing kan individuele verantwoordelikheid ook nie gedy nie. Die verantwoordelike lewe van gesinne moet ondersteun en beskerm word deur wetgewing. Luther sou in die volgende jare voortdurend aandring op sosiaal-regtelike hervormings. Danksy sy aandrang is begrippe soos 'armoede' noukeuriger gedefinieer vir die doeleindes van wetgewing. Wette wat onreg nie doelmatig kon bekamp nie, is aangepas en nuwe wette vir nuwe uitdagings en situasies is geskryf (vgl. Lück 2007:206-212).

Alle Christelike argumentvoering oor ekonomie loop uiteindelik uit op 'n besinning oor die liefde. Christelike liefde moet vanuit die Christelike vryheid beredeneer word, indien dit getrou wil bly aan die Bybel. In Luther se geskrif Oor die vryheid van ' $n$ Christenmens (Luther 1520), aanvanklik gepubliseer in Latyn (Tractatus de libertate Christiana - WA $7,49-67)$ en kort daarna in Duits vertaal en verwerk (Von der Freiheit eines Christenmenschen - WA 7, 20-38 )3 , kry 'n mens sy bekende en klassieke uitsprake oor die liefde en die vryheid:

Sodat ons grondig mag weet wat 'n Christenmens is en hoe dit met sy vryheid gesteld is, wat vir hom deur Christus verwerf en aan hom geskenk is, waarvan die apostel Paulus so baie skryf, wil ek die volgende twee stellings opstel:

- ' $n$ Christenmens is ' $n$ vrye heer oor alle dinge en niemand se onderdaan nie.

- 'n Christenmens is 'n diensbare kneg van alle dinge en aan almal onderdanig. ${ }^{4}$ (Outeur se vertaling)

Hierdie dubbele stelling verwys terug na 1 Korintiërs 9:19 en Romeine 13:8. Op grond van die uitskakeling van twee gedagtes $e k$ is vry van alle dinge en julle moet aan niemand iets verskuldig wees nie, konkludeer hy dan dat liefde neerkom op diensbaarheid en onderdanigheid aan dié een wat jy liefhet. Vanuit bogenoemde paradoksale stelling het Luther 'n paradoksale antropologie ontwikkel wat neerkom op

3.'n Moderne Duitse vertaling is beskikbaar in Luther [1520] [1981] 1991d. Ek haal egter aan uit die Weimarer Ausgabe (WA).

4.'Das wir grundlich muegen erkennen / was eyn Christen mensch sey / vnd wie es gethan sey / vmb die freyheyt / die yhm Christus erworben vnd geben hatt / dauon Sankt Paulus viel schreybt / will ich setzen / dyße zween beschluß: Eyn Christen mensch ist ein freyere herr / uober alle ding / vnd niemandt vnterthan. Eyn Christen mensch ist eyn dienstpar knecht aller ding vnd yderman vnterthan.' vryheid in geestelike dinge en knegskap in wêreldlike dinge. Sy (WA 7, 38, 6-15) verstaan van geloof, menswees en moraliteit word dan aan die einde van hierdie geskrif soos volg saamgevat:

Uit alles [wat gesê is] volg die volgende konklusie; dat 'n Christenmens nie in homself lewe nie, maar in Christus en sy naaste: In Christus deur die geloof, in die naaste deur die liefde. Deur die geloof vaar hy opwaarts na God, van God vaar hy weer afwaarts deur die liefde en bly dan altyd in God en die Goddelike liefde. Dit is, soos wat Christus in Johannes 1:51 sê: 'Julle sal nog die hemel oop sien staan en die engel op- en afstyg bokant die Seun van die Mens'. Kyk, dít is die regte, geestelike vryheid, wat die hart van alle sonde, wette en gebooie vrymaak. Dit oortref alle andere vryhede wat daar in die hemel en die aarde mag wees. Mag God gee dat ons dit reg verstaan en daaraan vashou! Amen. ${ }^{5}$ (Outeur se vertaling)

In 1528 skryf Luther (1528, WA 26, 294-30, 305) sy geskrif Vom Abendmahl Christi. Bekenntnis (Aangaande die Nagmaal van Christus. ' $n$ Belydenis). In hierdie boekie kom hy terug op die drie-stande-teorie. Hy beklemtoon dat die goeie versorging van kinders en kinders se gehoorsaamheid aan hulle ouers 'heilige werke' is. Hy (WA 26, 504, 30-305, 10) sê:

Maar die heilige ordes en regte instellings wat deur God ingestel is, is die volgende drie: Die priesteramp, die huwelik en die wêreldlike owerheid. Almal wat [dien] in die amp van predikant of dienaar van die Woord, bevind hulle in 'n heilige, regte en goeie orde en stand wat [deel uitmaak] van God se wil. [Hierdie stand behels] diegene wat preek, die sakramente bedien, die gemeenskapskas bestuur, asook diegene wat as koster, amptenare, ensovoorts, diens doen. Hierdie werk is suiwer heilige diens aan God. Net so is diegene wat vader en moeder is, wat die huishouding goed regeer, en kinders opvoed tot diens van God ook besig met heilige werk en [bevind] hulle in 'n heilige orde. Dieselfde geld waar kinders of die gesin die ouers of hoofde gehoorsaam is. Wie hulle hieraan hou, lewe soos 'n heilige op aarde. Dieselfde geld die vors of die owerste, regter, amptenare, kanselier, skrywer, knegte en bediendes en almal wat sulke dienswerk verrig en onderdanig en gehoorsaam is - almal is besig met absolute heiligheid en lewe heilig vir God. Om hierdie rede word hierdie drie instellings of ordes in God se Woord en gebod opgeneem. Wat in God se Woord opgeneem word, moet 'n heilige ding wees, aangesien God se Woord heilig is en alles belig wat daarin opgeneem word. ${ }^{6}$ (Outeur se vertaling)

5.'Au $\beta$ dem allenn folger der beschlü / das eyn Christen mensch lebt nit ynn yhm selb I sondern ynn Christo vand seynem nehstenn / ynn Christo durch den glauben / ym nehsten / durch die liebe [oder er ist kein Christ/] durch den glauben ferer er [wird nehsten / durch die liebe [oder er ist kein Christ/] durch den glauben ferer er [wirc er hinauf gerissen] vber sich yn gott / aus gott ferer er [gleitet er] widder vnter sich durch die liebe / vnd bleybt doch ymmer yn gott vnd gottlicher liebe / Gleych wie Christus sagt Johan 1. [51]. Ihr werdet noch sehen den hymell offen stehn / vnd die Engell auff vnd absteygen vbir den Sun des menschen. Sihe, das ist / die rechte / geystliche / Christliche freyheyt / die das hertz frey macht / von allen sundenn / gesetzen / vnd gepotten / wilche alle andere freyheyt vbirtrifft / wie der hymell die erdenn / Wilch geb vns gott recht zuuorstehen vnd behaltenn / AMEN.'

6.'Aber die heiligen orden vnd rechte stiffte von Gott eingesetzt hat, sind diese drey. Das priesteramt / Der Ehestand / Die weltliche oeberkeit / Alle die so ym pfaramp odder dienst des worts funden werden/ sind ynn einem heiligen / rechten / guten / Gott angenemen orden vnd stand / als / die da predigen / sacrament reichen / dem gemeinen kasten furstehen / kuester vnd boten odder knechte /so solchen personen dienen etc. Solchs sind eitel heilige werck fuer Gott / Also wer Vater vnd mutter ist / haus wol regirt / vnd kinder zeucht zu Gottes dienst / ist auch eitel heiligthum vnd heilig werck vnd heiliger orden / Des gleichen wo kind odder gesind / den Eldern heilig werck vnd heiliger orden / Des gleichen wo kind odder gesind / den Eldern odder herrn gehorsam sind / ist auch eitel heiligkeit / vnd wer darynn funden wird / der ist ein lebendiger heilige auff erden. Also auch furst odder oberherr / richter / amptleute / Cantzler / schreiber / knechte / megde / vnd alle die solchen dienen dazu alle die vitertheniglich gehorsam sind/alles eitel heiligthum/vnd heilig leben fur Gott / Darumb das solche drey stiffte odder orden ynn Gottes wort vnd gebot gefasset sind / Was aber ynn Gottes wort gefasset ist / das mus heilig ding sein / denn Gottes wort ist heilig vnd heiliget alles / das an yhm vnd ynn yhm ist.' 
Ten spyte van die feit dat Luther 'goeie werke' as 'heilig' beskryf, onderskei hy streng tussen 'wêreldlike werke' en 'geestelike werke'. Wêreldlike goeie werke kan selfs bydra tot dít wat God in die wêreld tot werklikheid wil laat kom, maar dit kan nie bydra tot ons saligheid nie. Hy (WA 26, 505, 11-20) sê:

Maar hierdie drie instellings en ordes vorm deel van die algemene orde van die Christelike liefde. Die gevolg is dat ' $n$ mens nie alleenlik die drie ordes [of samelewingsverbande] nie, maar ook ander mense deurlopend dien; onder andere deur hongeriges te voed, dorstiges te les, ensovoorts, vyande te vergewe, voorbidding te doen vir alle mense op aarde, allerlei boosheid op aarde te ly, ensovoorts. Sien, dit is alles suiwer goeie werke! Nogtans is nie een van hierdie ordes [of werke] 'n weg na die saligheid nie. Die enigste weg, bo al hierdie dinge, is die geloof in Jesus Christus. Daar is 'n groot verskil tussen heiligwees en salig-wees. Salig word ons alleen deur Christus. Heilig word ons deur sowel die geloof as die Goddelike instellings en ordes. Dit kan wees dat goddeloses wel heilige dinge doen, maar dít maak hulle nie salig nie. God verwag wel sulke werke van ons tot sy lof en eer. Almal wat danksy geloof in Christus salig word, doen sulke werk en eerbiedig sulke ordes. ${ }^{7}$ (Outeur se vertaling)

'n Kort samevatting van Luther se ekonomiese etiek kan in sy Kategismusse (1529) gelees word. Die uitleg van die sewende en negende gebooie vat in 'n groot mate saam wat hy oor 'n dekade lank ontwikkel het. Dit sal ons as Gereformeerde / Hervormde lidmate goed doen om ook na sy uitleg van hierdie gebooie volgens die Klein Kategismus te luister:

\section{Jy mag nie steel nie. \\ Wat beteken dit?}

Antwoord: Ons moet God vrees en liefhê, sodat ons nie ons naaste se geld en eiendom vat of dit met valse ware of handelstransaksies bekom nie, maar hom eerder help om sy goed en besigheid te verbeter en te beskerm. ${ }^{8}$ (Outeur se vertaling van 1991e: 143-144 = WA 30, I, 359)

Jy mag nie jou naaste se huis begeer nie.

Wat beteken dit?

Antwoord: Ons moet God vrees en liefhê, sodat ons nie met skelmstreke of 'n skyn van reg sy erfgoed of huis probeer bekom nie, maar hom help en van diens wees om dit te behou. ${ }^{9}$ (Outeur se vertaling van 1991e:144 = WA 30, I, 360-361)

\section{7.'Vber diese drey stifft vnd orden / ist nu der gemeine orden der Christlichen liebe / darynn man nicht allein den dreyen orden / sondern auch ynn gemein einem iglichen duerfftigen mit allerley wohltat dienet / als speisen die hungerigen / trencken die duerffigen mit allerley wohltat dienet / als speisen die hungerigen / trencken die
duerstigen etc. vergeben den feynden / bitten fur alle menschen auff erden / leiden duerstigen etc. vergeben den feynden / bitten fur alle menschen auff erden / leiden
allerley boeses auff erden etc. Sihe / das heissen alles eitel gute heilige werck / allerley boeses auff erden etc. Sihe / das heissen alles eitel gute heilige werck /
Dennoch ist keiner solcher oerden ein weg zur seligkeit / Sondern bleibt der einige Dennoch ist keiner solcher oerden ein weg zur seligkeit / Sondern bleibt der einige
weg vber diese alle / nemlich der glaube an Ihesum Christum / Denn es ist gar viel weg vber diese alle / nemlich der glaube an Ihesum Christum / Denn es ist gar viel
ein anders / heilig vnd selig sein. Selig werden wir allein durch Christum / Heilig aber beide durch solchen glauben vnd auch durch solche Göttliche stiffte vnd orden. Es mueen auch gottlose wol viel heiliges dinges haben / sind drumb nicht selig drynn / Denn Gott will solche werck von vns haben zu seinem lob vnd ehre / Vnd alle die so ynn dem glauben Christi selig sind / die thun solche werck / vnd halten solche} orden

8.'Du sollst nicht stehlen. Was ist das? Antwort: Wir sollen Gott fürchten und lieben, daB wir unsers Nächsten Geld oder Gut nicht nehmen noch mit falscher Ware oder
Handel an uns bringen, sondern ihm sein Gut und Nahrung helfen bessern und behüten.'

9.'Du sollst nicht begehren deines Nächsten Haus. Was ist das? Antwort: Wir

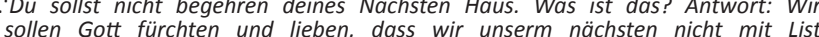
sollen Gott fürchten und lieben, dass wir unserm nachsten nicht mit List
nach seinem Erbe oder Haus stehen und mit einem Schein des Rechts an uns bringen, sondern ihm dasselb[ige] zu behalten förderlich und dienstlich sein.'

\section{Oor koophandel en woeker ${ }^{10}-1524$}

Voordat daar na Luther se argumente gekyk word, eers iets oor die historiese aanloop tot sy betoog. Alreeds in die Vroeë Kerk is daar met beroep op Deuteronomium 23:20 en Lukas 6:35'n verbod op rente geplaas. Pous Leos I (440-461 n.C.) het geldmaak uit rente-opbrengs as die dood van die siel beskryf (Fenus pecuniae funus est animae). In die elfde eeu het hierdie saak weer na vore gekom as gevolg van die internasionale handel wat deur die kruistogte moontlik gemaak is. Tussen die twaalfde en veertiende eeue het grootskaalse verstedeliking plaasgevind, en daarmee saam die ontwikkeling van geldhandel. In hierdie tyd is die tradisionele renteverbod herhaal. Op die tweede, derde en vierde Lateraanse Konsilies (1245-1274) en die Konsilie van Wenen (1311/1312) is die 'woekerverbod' geformuleer en verfyn. Hierdie wette is gemaak gedagtig aan die plig om weldadigheid en die bekamping van gewinsug, asook die beskerming van gewone mense teen uitbuiting. Eers teen die vyftiende eeu is besef dat die ou tradisionele renteverbod nie tred gehou het met die ontwikkeling van die ekonomie nie. Die Pouse Martinus V (1425) en Kalixtus III (1455) het belasting- en rente-opbrengs gelegitimeer. Binne hierdie klimaat van nuwe denke het Luther op die toneel gekom. ${ }^{11}$

Om hierdie spesifieke geskrif na behore te verstaan, is die volgende historiese inligting ook van belang. Luther het hom vier keer uitvoerig oor ekonomiese temas uitgelaat (vgl. Lapp 2012:92-95). In 1519 skryf hy Eyn Sermon von dem Wucher ('n Preek oor die Woeker) - ook bekend as die Kleiner Sermon von dem Wucher (WA 6, 1, 3-8). In 1520 verskyn daar 'n verwerkte weergawe van hierdie preek, bekend as die Große Sermon von dem Wucher (WA 6, 33, 36-60). Die agtergrond van hierdie preke het met die kerklike finansies en die uitbuiting van die boere te make gehad. Die belangrikste punt is dat die bergrede van iemand verwag om te leen sonder om daarvoor beloon te word. Die derde uitvoerige geskrif word hieronder bespreek. Die vierde was 'n vermaning aan die predikante in 1539/1540 om oor die woekerpraktyke te preek: An die Pfarrherrn wider den Wucher zu predigen (WA 51, 324, 331-424). Die agtergrond het met die droogte en hongersnood van 1539 te make gehad. In hierdie situasie kan nie toegelaat word dat mense uitgebuit, verkul en besteel word nie.

Luther begin sy betoog deur te stel dat daar onder die handelaars (Kaufleuten) sondaars en boosdoeners is. Die wortel van hierdie wandade moet teruggevoer word na die 'begeerlikheid' (1 Tim 6:9). In die lig van die evangelie moet hierdie wanpraktyke veroordeel word. Luther stel

10.Met 'woeker' bedoel Luther (vgl. Rieth 2010:149-158 en Lapp 2012:95-101)' $n$ hele aantal ekonomiese oneerlikhede. Dit sluit in: onbillike rente, prysmanipulasie, kartelvorming, onredelik hoë pryse, weerhouding van middele van die mark en kunsmatige vasstelling van die geldeenheid. Die wortel van al hierdie wanpraktyke moet volgens Luther teruggevoer word na die 'begeerlikheid' - die negende gebod.

11.Die tema 'rente' is ' $n$ omvangryke aangeleentheid wat in hierdie artikel nie breedvoerig aandag kan geniet nie. Sedert Hieronymus, Ambrosius, Augustinus en Thomas Aquinas is hierdie tema in aansluiting by Aristoteles gedebatteer. Belangstellendes kan na die resente artikel van Pawlas (2014:170-176) kyk vir Luther se bydrae in hierdie verband. Hy self het later in sy lewe gepleit vir 5\% rente (vgl. ook Schilling [2012] 2014:508-510). 
egter onmiddellik dat hy twyfel of sy geskrif enige iets aan die werklikheid sal verander, aangesien sommige hulle nie deur die evangelie laat aanspreek nie. Hy hoop egter dat diegene wat hulleself Christene noem, bereid sal wees om hulle gewetens te laat aanspreek. Insake koophandel, kom dit uiteindelik neer op die gewetensoordeel van enkelinge. As teoloog kan hy dus slegs poog om die gewetens van die Christene op te skerp (1991f:262-263 = WA 15, 293).

Handel tussen mense is 'n noodsaaklikheid. Ter wille van oorlewing móét mense ware ruil. Met handeldryf as sodanig is daar dus nie fout te vind nie. Ruilhandel of koophandel moet egter die welwese van die samelewing dien. Indien dit die prag en praal of vraatsug van enkelinge dien, behoort daar ingegryp te word. Volgens Luther tree probleme veral na vore wanneer daar op die internasionale handel gekonsentreer word, soos die invoer van uitspattige klere uit Indië. Deur ander ryk te maak, terwyl die plaaslike bevolking se nood vergeet word, is dwaas en sal nie kan standhou nie. Duitse handel is veronderstel om die Duitse bevolking te dien (1991f:264 = WA 15, 294).

Luther stel weer eens dat hy as teoloog slegs oor die misbruike en sondes van die handelaars kan skryf in soverre dit die gewete raak. Wanpraktyke wat die beurs (Beutel) raak (wat dalk die wisselkoers, inflasiekoers, handelsbalans en waarde van die geldeenheid insluit), is sake vir die owerhede. Die vorste en regeerders moet hulle mag gebruik om hier in te gryp. Hierdie dinge lê buite die bevoegdheid van die kerk, en teoloë kan aan hierdie sake niks doen nie (1991f:265 = WA 15, 294). Luther bespreek dan drie tipes 'woekerknoeiery' (Wucherkniffe) waaroor hy as teoloog wel iets kan sê:

\section{'Ek kan my ware so duur moontlik verkoop'}

Handelaars glo dit is hulle reg om hulle goedere so duur moontlik aan te bied vir aankope. Hierdie 'reg' is egter die begin van groot onreg en ellende. Hier word nie aan die naaste gedink nie, maar slegs aan eie gewin. Wie hierdie slagspreuk volg, bied geen ruimte aan die Christelike naasteliefde nie, en volg ook nie die natuurwet nie. Wie hierdie 'reg' wil volg, is eintlik besig om sy naaste te besteel. Pryse kan wel regmatig vasgestel word wanneer aan die moeite en gevaar van die handelaar gedink word - maar in die proses moet ook aan die nood en omstandighede van die naaste gedink word. Die handelaar moet ook daaraan dink hoe hy sy naaste sou kon help. Hy moet dus in die proses van prysvasstelling Christelik en menslik handel. Luther meen die volgende reël moet eerder in die handelsekonomie geld: 'Ek mag my ware so duur maak as wat dit veronderstel is om te wees, óf soos dit reg en billik is' (1991f:266 = WA 15, 295). Die rede vir hierdie reël is: Handel mag nie 'n bedryf raak, uitgelewer aan die mag en wil van die verkoper nie, maar moet gebonde bly aan die wet en die sin vir matigheid. Die handelaar moet pryse vasstel in ooreenstemming met sy gewete, sonder benadeling van sy naaste. Die handelaar kan nie werklik deur ander gehelp word nie. Iemand (ook nie die owerhede nie) kan nie pryse vasstel nie, aangesien insetkoste, onkoste en omstandighede aanhoudend verander. Die handelaar se moeite, arbeid en gevaar moet egter regmatig beloon word (Luk 10:7). Hoe word dit egter verseker? Luther meen dat in enkele gevalle prysbeheer wel deur amptenare verseker kan word - maar dít werk maar selde. Om hierdie rede moet pryse deur die vrye markte bepaal word. Maar uiteindelik kom dit neer op die gewete en integriteit van die handelaar. Heel nugter weet Luther dat iemand hier en daar 'n bietjie te veel wins gaan maak ('n onvermydelike sonde noem hy dit) - en daarom moet hy maar gereeld bid vergewe my my skuld (1991f:265-269 = WA 15, 295-298).

\section{'Wanneer een vir' $n$ ander as borg optree, kan daar uitbuiting wees'}

Om as borg vir ' $n$ ander op te tree, is as sodanig nie verkeerd nie - dit kan selfs as 'n daad van liefde beskou word. Die probleem is egter dat daar talle wanpraktyke voorkom wat nie met die Christelike etiek versoenbaar is nie.

Voordat hy hierdie wanpraktyke beskryf, noem hy eers drie maniere hoe daar Christelik teenoor die naaste in die ekonomie opgetree moet word:

- In navolging van Matteus 5:40 moet ons toelaat dat mense ons goed steel, sonder om dit terug te vra. Aan hierdie eis kan net ware Christene voldoen. Dít kan nie 'n algemene riglyn vir handelaars wees nie. Ware Christene kan só lewe, aangesien hulle met die verwagting in Matteus 6:11 lewe dat Christus aan hulle hul daaglikse brood sal gee. Sou mense in die algemeen só lewe, sou die ekonomie gesuiwer kon word van allerlei wanpraktyke.

- Volgens Matteus 5:42 moet ons gee en leen aan diegene wat iets van ons vra. Ook hierdie riglyn kan nie algemeen menslik afgedwing word nie - slegs Christene met 'n uitsonderlike morele gesindheid en 'n vaste geloof dat God hulle nooit sal versaak nie (Jos 1:5), kan aan hierdie eis voldoen.

- Volgens Lukas 6:34 moet ons nie geld leen net aan diegene van wie ons hoop om dit terug te kry nie. Ons moet vrygewig aan almal leen, al kan ons nie verwag dat ons ons leengoed noodwendig terug sal kry nie. Hierteenoor wil die borg terugontvang - hy wil selfs somtyds méér ontvang as wat hy geleen het - en dít is wat onaanvaarbaar is. Om borg te teken, is nie noodwendig verkeerd nie; die misbruik van borg om ander uit te buit (wat een gestalte van "woeker" is), is wat verkeerd is (vgl. 1991f:269-271 = WA 15, 298-302).

\section{Hoe die Bybel verstaan moet word? Die onderskeiding van wet en evangelie}

Die noodwendige vraag wat uit die voorafgaande na vore kom, is óf enige iemand die saligheid kan beërwe, aangesien niemand aan hierdie eise kan voldoen nie. Aangesien hierdie Christelike eise nie algemene ekonomiese beginsels kan wees nie, bestaan die vrees dat die boosheid in hierdie wêreld sal gedy, omdat daar dan geen morele beginsels is waaraan die handelaars hulle kan hou nie. Luther verduidelik dan een van die basiese Reformatoriese grondbeslissings, naamlik die onderskeiding tussen wet en evangelie. 
Die wêreld kan nie met die evangelie regeer word nie. Die wêreld, met al sy boosheid, moet deur die wet, mag en geweld regeer word. Die staat (of die owerheid) moet reg en vrede skep en bewaar deur middel van wette en die straf van oortreders (Rom 13:4). Tussen Christene kan daar sprake wees van borgskappe en die leen van geld en goedere, aangesien verwag kan word dat hulle eerbaar teenoor mekaar sal optree. Van heidene kan dít egter nie verwag word nie, en daarom moet die owerheid, met dwang, toesien dat mense op 'n moreel aanvaarbare wyse teenoor mekaar optree. Teenoor heidene moet Christene nog steeds Christelik optree, en wel met die bereidwilligheid om onreg te ly (1 Kor 6:7). Indien iemand genoeg het om te gee en/of te leen, móét hy dit doen. Elke Christen moet egter verstandig te werk gaan. Ons eerste verpligting is teenoor ons gesin en familie, en daar kan nie uitgedeel word op 'n skaal wat jou eie mense in gevaar stel nie. Goeie gesonde verstand moet die liefde en hulpvaardigheid van die Christen begelei (1991f:271-273 = WA 15, 302-303).

\section{Koop en verkoop met kontant en ruilhandel}

Aangesien mense sondaars is en met boosheid teenoor mekaar optree, is dit die beste om iemand kontant te laat betaal. Teenoor Christene kan die houding tog anders wees, en kan daar ander reëlings getref word. Mense kan geld geleen word, hulle kan 'op skuld koop' en iemand kan as borg optree. Maar, ook Christene is sondaars en onetiese gedrag kan ook van hulle verwag word. Daarom bly dit beter om so ver moontlik transaksies kontant af te handel. Hy waarsku teen die volgende:

- Indien iets op krediet verkoop word, is die prys altyd hoër as met kontant. Handelaars wil daarom graag hê dat kopers op krediet (op skuld) sal koop. Dít is egter $\mathrm{dwaas}$, teen die rede in en dikwels gewoon oneties. Om hierdie rede verhinder die Goddelike reg die verkoop van goedere op 'n ander wyse as kontant, aangesien God wil keer dat kopers uitgebuit word (Lev 25:35-40).

- Dit is ook oneties om goedere duurder te verkoop as 'markprys'. ${ }^{12}$ Om voor te gee dat daar 'n skaarste is en daarom goedere duurder as gewoonlik te verkoop, is gewoon diefstal.

- Diegene wat goedere opkoop of laat opkoop om dit dan so duur moontlik aan te bied, begaan 'n gruwelike sonde. Wie 'n monopolie op hierdie wyse opbou, verdien straf.

- Wie 'n monopolie opbou deur ander te dwarsboom om hulle goedere op dieselfde mark te verkoop, verdien nie om 'n mens genoem te word nie. Hierdie tipe naywer en gierigheid moet deur die owerheid swaar gestraf word.

- Dit is net so laakbaar om iets wat jy nie werklik het nie, aan iemand te verkoop. Om iemand te laat betaal vir iets wat jy nie het nie, en dan eers te gaan om dit by 'n ander goedkoper te gaan koop, is nie eerbaar nie. Die beginsel van vergoeding vir gevaar, moeite en arbeid word op hierdie wyse ondergrawe.

12.Vanselfsprekend kan ons nie ons huidige kapitalistiese-markgedrewe ekonomiese sisteem in Luther teruglees nie. Om egter te beweer dat die wêreld van 500 jaar gelede geen verbande met die huidige vertoon nie, is nie korrek nie. Die wereld het 'maties verander, maar sekere verskynsels is tipies menslk. Daar was nog altyd markte', en die 'markpryse' is nog altyd, van tyd tot tyd, kunsmatig gemanipuleer Kyk na Schilling ([2012] 2014:506-523) vir die vae ekonomiese verwantskappe tussen ons en Luther.
- Nog 'n wanpraktyk is om goedere slegs in die groot stede te koop aan te bied met die argument dat dit op die platteland onkoopbaar duur sou wees - terwyl die stadsprys buitensporig hoog is. Dít is bedrog en veral arm mense word skaamteloos uitgebuit.

- 'Kartelvorming' is ook eties onaanvaarbaar. Die lede van die kartel behoort swaar gestraf word, aangesien daar nie 'n ander manier is om hierdie wanpraktyk te stop nie.

- Prysmanipulering ten bate van sekere handelaars moet ook veroordeel word. Om pryse ewe skielik goedkoper te maak wanneer bepaalde mense aankope doen en dit dan weer duurder te maak wanneer ander hulle aankope moet doen, is nie billik nie en moet veroordeel word.

- Om groot hoeveelhede aan te koop op skuld, met die bedoeling om dit duurder te herverkoop, moet ook strafbaar wees deur die owerhede.

- Skelmstreke op die mark moet deur die owerheid uitgesnuffel word. Dinge soos: skale wat verkeerd weeg, om onder in 'n kis 'n klomp vrot appels te sit en om voor te gee dat egte juwele en kruie verkoop word terwyl dit nie eg is nie (vgl. 1991f:273-281 = WA 15, 303-312).

Luther sluit sy betoog af deur te vermaan dat matigheid en eerlikheid die hoekstene van die gemeenskap moet wees, aangesien " $n$ ewige seker Penning beter is as 'n tydelike onseker Gulde' (1991f:281 = WA 15, 312). Konings en vorste moet toesien dat daar eerbaarheid in die ekonomie heers. Die probleem is egter dat hulle dikwels aandeel het aan die onreg (Jes 1:23). Dit is soms lagwekkend dat daar van die groot diewe verwag word om die klein diewe te straf. Die enigste troos is dat die klein diewe vroeër of later wraak gaan neem op die groot diewe wat hulle straf. Verder moet Christene die vertroue in God se oordeel behou dat Hy die onreg nie ongestraf sal laat nie. Van reg en redelikheid in die ekonomie is daar nie veel sprake nie. Van Christene word egter verwag om in goeie wil te handel (1991f:281-283 = WA 15, 313).

\section{Samevatting}

Luther was bewus van talle wanpraktyke in die ekonomie. Hy was oortuig dat hy as teoloog hierdie booshede moes ontbloot - wel wetende dat nie-Christene hulle nie aan hom sal steur nie. Hy skryf daarom vir die lidmate van die kerk sowel as die Christenvorste. Hy skryf met die bedoeling om hulle gewetens aan te spreek. Hulle moet binne die ekonomie soos Christene optree - 'n verwagting waaraan nie-Christene nie kan voldoen nie aangesien die eise van die Nuwe Testament té radikaal is. Die vorste moet deur wetgewing onreg en diefstal probeer beheer en beperk. Op hierdie wyse lewer hy 'n bydrae tot die definiëring van diefstal, aangesien dít vele gestaltes en mutasies het.

Luther se beweegrede vir sy bemoeienis met die ekonomie het met sy pastorale gevoel te make. As pastor moet hy probeer om armoede en siekte te beveg. Hy wil nie die wêreld met die evangelie regeer nie, maar deur onderrig oor die wet bydra tot 'n vreedsame en regverdige samelewing. Luther het nie gepoog om die ekonomie grootskaals te verander nie. Hy het sy eie bydrae as beskeie beskou. Hy wou pastor bly en 
het nie gepoog om 'n ekonomiese teorie te ontwikkel nie. Hy het nogtans gepoog om vanuit die regverdigingsleer en die 'redelikheid van Christelike optrede' (vgl. Pawlas 2014:170175 oor die verband tussen rede en naasteliefde) by te dra tot menslike waardigheid vir arm en siek mense.

\section{Samevattende beoordeling}

By Luther leer ons dat teologie ten diepste te make het met die onderskeiding tussen wet en evangelie. Die werke van die wet dra nie by tot die mens se saligheid nie, maar as Christene is ons verplig om volgens die eise van die wet, soos Christus dit uitgelê het, te lewe. Ons word deur die geloof geregverdig, maar die doen van goeie werke bly ons plig (vgl. Luther se preek van 1522 oor Luk 16:1-9 en die 'ongeregverdigde Mammon' - Dembek 2012). Die konsekwensie van hierdie vertrekpunt is dat die evangelie nie as 'n handleiding vir die ekonomie gebruik kan word nie, maar dat die morele eise van die evangelie minstens deur die Christene gehoorsaam moet word. Op grond van hulle gewetensbeslissings moet hulle poog om relatiewe verbeterings aan die ekonomiese sisteem aan te bring. Hierdie benadering het sy waarde deur die loop van die eeue behou. Ons kan vandag ook nie juis hoop om méér te bereik nie. Teoloë en Christene kan onreg en diefstal nie keer nie. Daar kan slegs gepleit word vir eerbaarheid en geregtigheid. Ons kan en moet by die owerhede aandring op wetgewing wat ekonomiese misdade kan temper, maar sal moet berus in die ontstellende wete dat die magsdraers dikwels die grootste skelms is. Die eindoordeel bly ons enigste troos.

Die blootlegging van ekonomiese misdade bly Christenplig. Die uitwys en definiëring van ekonomiese onreg en misdaad moet voortgaan. Indien ons dit nie wil doen nie, verraai ons dalk ons deelname aan praktyke wat in stryd is met die sewende en negende gebooie.

Ná 500 jaar bly Martin Luther interessant en relevant. Ons moet net nie dink dat hy ingespan kan word om die een of ander ekonomiese ideologie te regverdig nie. Hy was nie 'n ekonoom nie, maar 'n teoloog. Hy het gewaarsku teen die neiging om Mammon God te maak. Verder het hy probeer om mense te oortuig om uit liefde teenoor die naaste op te tree - liefde wat die naaste nie uitbuit, verkul en besteel nie. Laastens het hy gewone mense aangemoedig om spaarsamig te lewe, aangesien geld 'n onseker en wankelbare ding is / denn es ist geld ein ungewis, wanckelbar ding - (WA 51, 347, 20).

\section{Erkenning Mededingende belange}

Die outeur verklaar hiermee dat hy geen finansiële of persoonlike verbintenis het met enige party wat hom nadelig of voordelig kon beïnvloed het in die skryf van hierdie artikel nie.

\section{Literatuurverwysings}

Beyer, M., 2007, 'Theologische Grundlagen für Martin Luthers Sozialengagement', in S. Oehmig (Hrsg.), Medizin und Sozialwesen in Mitteldeutschland zur Reformationszeit, pp. 53-72, Evangelische Verlagsanstalt, Leipzig. (Schriften der Stiftung Luthergedenkstätten in Sachsen-Anhalt, Bd 6).

Brandt, R., 2011, 'Sorget nicht!: Luthers Auslegung von Mt 6,25a.28-30 - in seinem Garten vergegenwärtigt', Luther 82(1), 2-4.

Bräuer, H., 2007, 'Armsein in obersächsischen Städten um 1500', in S. Oehmig (Hrsg.), Medizin und Sozialwesen in Mitteldeutschland zur Reformationszeit, pp. 25-52, Evangelische Verlagsanstalt, Leipzig. (Schriften der Stiftung Luthergedenkstätten in Sachsen-Anhalt, Bd 6).

Dembek, A., 2012, 'Von wahrem Glauben und sichtbaren Werken: Luthers "Sermon von dem unrechten Mammon" von 1522', Luther 83(3), 128-132.

Jütte, R., 2007, 'Die Sorge für Kranke und Gebrechliche in den Almosen- und Kastenordnungen des 16. Jahrhunderts', in S. Oehmig (Hrsg.), Medizin und Sozialwesen in Mitteldeutschland zur Reformationszeit, pp. 9-21, Evangelische Verlagsanstalt, Leipzig. (Schriften der Stiftung Luthergedenkstätten in SachsenAnhalt, Bd 6).

Lapp, M., 2012, 'Denn es ist geld ein ungewis, wanckelbar ding: Die Wirtschaftsethik Martin Luthers anhand seiner Schriften gegen den Wucher', Luther 83(2), 91-107.

Lück, H., 2007, 'Armen- und Fürsorgeordnungen der Reformationszeit - Anfänge eines neuzeitlichen Sozialrechts?', in S. Oehmig (Hrsg.), Medizin und Sozialwesen in Mitteldeutschland zur Reformationszeit, pp. 197-212, Evangelische Verlagsanstalt, Leipzig. (Schriften der Stiftung Luthergedenkstätten in SachsenAnhalt, Bd 6).

Luther, M., 1883-1993, Weimarer Ausgabe (WA), D. Martin Luthers Werke: Kritische Gesamtausgabe, 65 Volumes, H. Bhlau, Weimar.

Luther, M., 1519, 'Kleiner Sermon von dem Wucher', Weimarer Ausgabe 6, 1, 3-8.

Luther, M., 1520, 'Großer Sermon von dem Wucher', Weimarer Ausgabe 6, 33, 36-60.

Luther, M., 1528, 'Vom Abendmahl Christi. Bekenntnis', Weimarer Ausgabe 26, 294-30, 305.

Luther, M., 1539/1540, 'An die Pfarrherrn wider den Wucher zu predigen', Weimarer Ausgabe 51, 324, 331-424.

Luther, M., [1517] [1981] 1991a, 'Die Ablassthesen und Resolutionen', in Luther Deutsch. Die Werke Luthers in Auswahl. Hg von Kurt Aland. Band 2: Der Reformator, Zweite durchgesehene Auflage, pp. 32-82, Vandenhoeck, Göttingen.

Luther, M., [1520] [1981] 1991b, 'Von den guten Werken', in Luther Deutsch. Die Werke Luthers in Auswahl. Hg von Kurt Aland. Band 2: Der Reformator, Zweite durchgesehene Auflage, pp. 95-156, Vandenhoeck, Göttingen.

Luther, M., [1520] [1981] 1991c, 'An den christlichen Adel deutscher Nation von des christlichen Standes Besserung', in Luther Deutsch. Die Werke Luthers in Auswahl. $\mathrm{Hg}$ von Kurt Aland. Band 2: Der Reformator, Zweite durchgesehene Auflage, pp. 157-170, Vandenhoeck, Göttingen.

Luther, M., [1520] [1981] 1991d, 'Von der Freiheit eines Christenmenschen', in Luther Deutsch. Die Werke Luthers in Auswahl. Hg von Kurt Aland. Band 2: Der Reformator, Zweite durchgesehene Auflage, pp. 251-274, Vandenhoeck, Göttingen.

Luther, M., [1529] [1983] 1991e, 'Der Kleine Katechismus', in Luther Deutsch. Die Werke Luthers in Auswahl. Hg von Kurt Aland. Band 6: Kirche und Gemeinde, Dritte durchgesehene Auflage, pp. 138-159, Vandenhoeck, Göttingen.

Luther, M., [1524] 1991f, 'Von Kaufshandlung und Wucher', in Luther Deutsch. Die Werke Luthers in Auswahl. $\mathrm{Hg}$ von Kurt Aland. Band 7: Der Christ in der Welt, pp. 263-283, Vandenhoeck, Göttingen.

Oehmig, S., 2007 'Über Arme, Armenfürsorge und Gemeine Kästen mitteldeutscher Städte der frühen Reformationszeit', in S. Oehmig (Hrsg.), Medizin und Sozialwesen in Mitteldeutschland zur Reformationszeit, pp. 73-114, Evangelische Verlagsanstalt, Leipzig. (Schriften der Stiftung Luthergedenkstätten in SachsenAnhalt, Bd 6).

Pawlas, A., 2014, 'Glaube und wirtschaftliche Vernunft bei Luther', Luther 85(3), 164-178.

Rieth, R., [2009] 2010, 'Luthers Antworten auf wirtschaftliche und soziale Herausforderungen seiner Zeit', Lutherjahrbuch 76, 137-158.

Schilling, H., [2012] 2014, Martin Luther: Rebell in einer Zeit des Umbruchs 3, durchgesehene Auflage, C.H. Beck, München.

Schirmer, U., 2007, 'Alltag, Armut und soziale Not in der ländlichen Gesellschaft', in S. Oehmig (Hrsg.), Medizin und Sozialwesen in Mitteldeutschland zur Reformationszeit, pp. 115-142, Evangelische Verlagsanstalt, Leipzig. (Schriften der Stiftung Luthergedenkstätten in Sachsen-Anhalt, Bd 6).

Van Wyk, N., 2010, 'Poverty: What should we say and do?', Theolgy and the Church in South Africa 2(1), 4-29. 